\title{
Inhaled nitric oxide and arterial oxygen tension in patients with chronic obstructive pulmonary disease and severe pulmonary hypertension
}

\author{
Yoshihiko Katayama, Timothy W Higenbottam, Maria J Diaz de Atauri, \\ George Cremona, Shinji Akamine, Joan Albert Barbera, Robert Rodrìguez-Roisin
}

Section of Respiratory Medicine, Floor F, The Medical School,

University of Sheffield, Sheffield S10 2RX, UK Y Katayama

T W Higenbottam

M J Diaz de Atauri

G Cremona

S Akamine

Servei de

Pneumologia,

Department of

Medicine,

Hospital Clinic,

Universitat de

Barcelona,

Barcelona, Spain

J A Barbera

R Rodriguez-Roisin

Correspondence to: Professor T W Higenbottam.

Received 18 December 1995 Returned to authors

16 February 1996

Revised version received

23 July 1996

Accepted for publication

5 August 1996

\begin{abstract}
Background - Inhaled nitric oxide (NO) is a selective pulmonary vasodilator which can improve gas exchange in acute lung injury. However, it is uncertain that this effect on arterial oxygenation can be generalised to all lung diseases.

Methods - The effects of inhaled NO on gas exchange were studied in nine patients with chronic obstructive pulmonary disease (COPD), 11 patients with severe pulmonary hypertension, and 14 healthy volunteers. A randomised sequence of $40 \mathrm{ppm}$ of NO or air was inhaled for 20 minutes through an orofacial mask.

Results - Inhaled NO reduced mean (SE) transcutaneous arterial oxygen tension $\left(\mathrm{TcPO}_{2}\right)$ from $9.6(0.3)$ to $8.9(0.4) \mathrm{kPa}$ in healthy volunteers and from $7.4(0.6)$ to $7.0(0.5) \mathrm{kPa}$ in patients with COPD. There was no change in $\mathrm{TcPO}_{2}$ in patients with severe pulmonary hypertension. During inhalation of NO and air no change occurred in transcutaneous arterial carbon dioxide tension $\left(\mathrm{TcPCO}_{2}\right)$, arterial oxygen saturation $\left(\mathrm{SaO}_{2}\right)$ measured by pulse oximeter, or cardiac output determined by the transthoracic impedance method.

Conclusions - Inhaled NO does not improve $\mathrm{TcPo}_{2}$ nor increase cardiac output in normal subjects and patients with COPD, suggesting that inhaled NO worsens gas exchange. This could represent inhaled NO overriding hypoxic pulmonary vasoconstriction in COPD. The finding that $\mathrm{TcPo}_{2}$ also fell when normal subjects inhaled NO suggests that a similar mechanism normally contributes to optimal gas exchange. Whilst inhaled NO can improve oxygenation, this effect should not be considered to be a general response but is dependent on the type of lung disease.

(Thorax 1997;52:120-124)
\end{abstract}

Keywords: nitric oxide, chronic obstructive pulmonary disease, pulmonary hypertension.

Nitric oxide (NO) is endothelium-derived relaxing factor. ${ }^{12}$ Vasorelaxation is caused by activation of soluble guanylate cyclase which increases the concentration of cyclic GMP in vascular smooth muscle. ${ }^{3}$ Inhaled NO in low concentration ( 40 parts per million ( $\mathrm{ppm})$ ) is a selective pulmonary vasodilator. ${ }^{4}$ It improves the arterial oxygenation of infants with per- sistent pulmonary hypertension of the newborn. ${ }^{5}$ In many patients with acute respiratory distress syndrome (ARDS) inhaled NO reduces the pulmonary artery pressure and increases arterial oxygenation by lessening intrapulmonary shunt. ${ }^{6}$ Experimentally, inhaled NO reverses hypoxic pulmonary vasoconstriction. ${ }^{7}$ Inhaled NO, however, can worsen gas exchange by overcoming the usual physiological mechanisms of matching ventilation (VA) and perfusion (Q). Whilst inhaled $\mathrm{NO}$ acts as a selective pulmonary vasodilator in some patients with chronic obstructive pulmonary disease (COPD), it fails to improve oxygenation. ${ }^{89}$ It is important to establish in which diseases inhaled NO fails to improve gas exchange. We have studied the change in arterial oxygenation during $\mathrm{NO}$ inhalation in patients with COPD and compared it with normal volunteers and patients with severe pulmonary hypertension.

\section{Methods}

Nine patients with COPD, 11 with severe pulmonary hypertension, and 14 healthy volunteers were studied. All gave their informed consent and the study was approved by the local hospital ethics committee. The diagnosis of COPD was established from a history of clinical and physiological evidence of irreversible airway obstruction. All patients with COPD ceased bronchodilators 12 hours before the study. The diagnosis of severe pulmonary hypertension was established by previous right heart catheterisation. All patients with severe pulmonary hypertension were receiving vasodilator therapy.

Measurements were made after breathing normal air or after breathing air with $40 \mathrm{ppm}$ $\mathrm{NO}$, both for 20 minutes. The order of giving the treatments was randomised and delivered in a single blind fashion.

The NO (British Oxygen Company Ltd, London, UK) was supplied in cylinders in a concentration of $10000 \mathrm{ppm} \mathrm{NO}$ in nitrogen. The inspired gas mixture of NO in air $(40 \mathrm{ppm})$ was prepared using an NO delivery system ${ }^{10}$ (PneuPAC Ltd, Luton, UK) which was delivered to the patients using a close fitting nasal mask (Nasal CPAP mask, Puritan-Bennett Corporation, Indianapolis, Indiana, USA) fitted with two one-way valves (fig 1 ). Continuous monitoring of the $\mathrm{NO}$ and nitrogen dioxide $\left(\mathrm{NO}_{2}\right)$ concentration in the inspirate was made by fuel cell monitors (Models EC90 and EC40, 


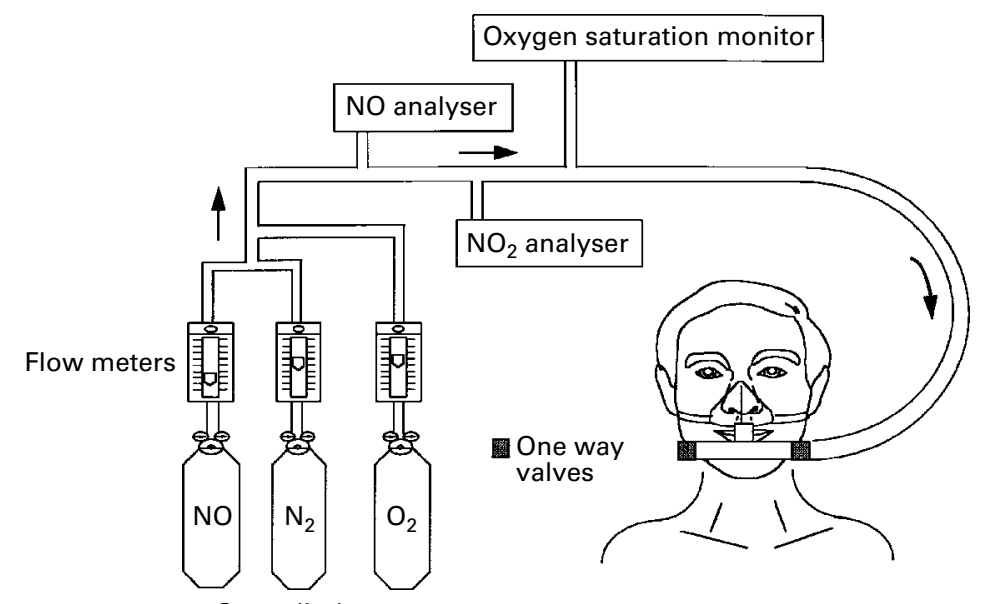

Gas cylinders

Figure 1 Nitric oxide delivery system.

Bedfont Scientific Ltd, Kent, UK). Each analyser was calibrated with a standard gas of 80 (1) $\mathrm{ppm} \mathrm{NO}$ in nitrogen and $10 \mathrm{ppm} \mathrm{NO}_{2}$ (British Oxygen Company Ltd, London, UK). The fractional inspired oxygen concentration $\left(\mathrm{FiO}_{2}\right)$ of the inhaled gas was monitored continuously using a portable oxygen monitor (TED 200-T, Teledyne Electronic Devices, City of Industry, California, USA). Air was supplied to the nasal mask by the same delivery system.

The venous blood methaemoglobin (Met$\mathrm{Hb} \%$ ) formed from inhaled NO was measured from samples collected from an antecubital vein before and after each inhalation period using a multiple wavelength spectrophotometric CO oximeter (IL282 CO-Oximeter, Instrumentation Laboratory, Lexington, Mas- sachusetts, USA). Total lung capacity (TLC) was measured by whole body plethysmography, and dynamic lung volumes (forced expiratory volume in one second $\left(\mathrm{FEV}_{1}\right)$ and forced vital capacity (FVC)) were measured with a dry wedge spirometer. Transcutaneous arterial oxygen and carbon dioxide tensions $\left(\mathrm{TcPO}_{2}\right.$, $\mathrm{TcPCO}_{2}$ ) were measured, respectively, by Servomed Oxymonitor and Servomed Kapnomonitor (Hellige GmbH, Freiburg im Breisgau, Germany). Arterial oxygen saturation $\left(\mathrm{SaO}_{2}\right)$ was measured by pulse oximeter (Pulsox-DP7, Minolta, Tokyo, Japan) and cardiac output by the transthoracic impedance method (NCCOM 3 cardiovascular monitor, BioMed Medica Manufacturing Inc, Irvine, California, USA). ${ }^{11}$

\section{STATISTICAL ANALYSIS}

Two way analysis of variance was used together with a paired Student's $t$ test to assess differences between treatments. $p$ values of less than 0.05 were considered significant. The results are expressed as mean and standard error.

\section{Results}

The $\mathrm{FEV}_{1}$ was 26 (9)\% predicted and the $\mathrm{FEV}_{1} / \mathrm{FVC}$ ratio was 38 (7)\% in patients with COPD (table 1). Most patients with severe pulmonary hypertension took calcium antagonists or angiotensin converting enzyme inhibitors. No patient was receiving treatment with continuous intravenous infusion of prostacyclin (table 2). The patients with severe pulmonary hypertension had high values of pulmonary vascular resistance (PVR). Inhaled $\mathrm{NO}$ reduced mean $\mathrm{TcPO}_{2}$ from $9.6(0.3) \mathrm{kPa}$ to $8.9(0.4) \mathrm{kPa}(\mathrm{p}<0.05)$ in healthy volunteers and from $7.4(0.6) \mathrm{kPa}$ to $7.0(0.5) \mathrm{kPa}$ (p

Table 1 Mean (SE) data for patients and volunteers

\begin{tabular}{lclrllll}
\hline Number & $\begin{array}{l}\text { Age } \\
\text { (years) }\end{array}$ & M:F & $\begin{array}{l}F E V_{1} \\
(\% \text { pred })\end{array}$ & $\begin{array}{l}\text { VC } \\
(\% \text { pred })\end{array}$ & $\begin{array}{l}F E V_{1} / F V C \\
(\%)\end{array}$ & $\begin{array}{l}\text { Mean arterial pressure } \\
(m m \mathrm{Hg})\end{array}$ \\
\hline Volunteers & 14 & $32.2(2.1)$ & $10: 4$ & $101(5)$ & $98(4)$ & $94(4)$ & - \\
COPD & 9 & $69.0(2.0)$ & $5: 4$ & $26(9)$ & $50(10)$ & $38(7) *$ & - \\
Pulmonary hypertension & 11 & $32.4(2.0)$ & $4: 7$ & $73(7)$ & $77(7)$ & $86(5)$ & $59.1(5.0)$ \\
\hline
\end{tabular}

$\mathrm{FEV}_{1}=$ forced expiratory volume in one second; $\mathrm{VC}=$ vital capacity; $\mathrm{FVC}=$ forced vital capacity; COPD = chronic obstructive

${ }^{*} \mathrm{FEV}_{1} / \mathrm{FVC}$ was significantly lower in patients with COPD than in the other two groups $(\mathrm{p}<0.01)$.

Table 2 Haemodynamic data of the patients with pulmonary hypertension

\begin{tabular}{|c|c|c|c|c|c|c|c|c|}
\hline Age & Diagnosis & $\begin{array}{l}P p a \\
(m m \mathrm{Hg})\end{array}$ & $\begin{array}{l}\text { PVR } \\
\text { (dynes.s.cm }\end{array}$ & $\begin{array}{l}\text { SVR } \\
\text { (dynes.s.cm } \\
-5 \text { ) }\end{array}$ & $\begin{array}{l}C I \\
\left.1 . m^{-2} \cdot \min ^{-1}\right)\end{array}$ & $\begin{array}{l}\mathrm{PaO}_{2} \\
(\mathrm{kPa})\end{array}$ & $\begin{array}{l}\mathrm{SaO}_{2} \\
(\%)\end{array}$ & Treatment \\
\hline 34 & PPH & 54 & 18.8 & 31.3 & 1.3 & 8.5 & - & \multirow{11}{*}{$\begin{array}{l}\text { W, Heparin } \\
\text { W, Dil, Frusemide, } \\
\text { W, Dil, Frusemide, } \\
\text { W, Dil, Frumil, Digitoxin } \\
\text { W, Dil, Frumil, } \\
\text { Bendrofluazide, Thyroxine, } \\
\text { Dothiepin } \\
\text { W, Dil, Frumil } \\
\text { W, Dil } \\
\text { W, Dil } \\
\text { W, Dil } \\
\text { W, Dil, Frusemide, Frumil, } \\
\text { Prednisolone } \\
\text { Nasal oxygen }\end{array}$} \\
\hline 22 & PPH & 53 & $\begin{array}{l}15.6 \\
15.9\end{array}$ & 26.9 & 1.35 & 9.1 & 96 & \\
\hline 61 & PPH, thrombo & 47 & $\begin{array}{l}16.6 \\
16.6\end{array}$ & 37.9 & 1.3 & 8.0 & 95.2 & \\
\hline 32 & PPH & 54 & 23 & 31.5 & ${ }_{-}^{1.3}$ & $\begin{array}{l}0.0 \\
7.7\end{array}$ & 87.2 & \\
\hline 51 & PPH & 40 & 8.3 & 30.5 & 2 & 8.8 & 94 & \\
\hline 58 & PPH, thrombo & 72 & 20 & 32.8 & 1.65 & 8.3 & 91 & \\
\hline 24 & PPH & 75 & 17.6 & 22.4 & 2.2 & 9.6 & 94 & \\
\hline 26 & PPH & 80 & 16.2 & 21.4 & 1.8 & 9.7 & 96 & \\
\hline 29 & $\mathrm{PPH}$ & 83 & 17.9 & 23.5 & 2.55 & 9.5 & 88 & \\
\hline 36 & SPH, sarcoidosis & 53 & 9.7 & 21.1 & 2.9 & 9.6 & 92 & \\
\hline 42 & SPH, CFA & 39 & 8 & 17.8 & 2.1 & 8.8 & 89 & \\
\hline
\end{tabular}

$\mathrm{Ppa}=$ pulmonary arterial pressure $\mathrm{PVR}=$ pulmonary vascular resistance; $\mathrm{SVR}=$ systemic vascular resistance $\mathrm{CI}=\mathrm{cardiac}_{\text {index }} ; \mathrm{PaO}_{2}=$ arterial oxygen tension; $\mathrm{SaO}_{2}=$ arterial oxygen saturation; $\mathrm{PPH}=$ primary pulmonary hypertension; $\mathrm{SPH}=$ secondary pulmonary hypertension; thrombo=secondary to pulmonary thromboembolism; $\mathrm{CFA}=$ cryptogenic fibrosing alveolitis; $\mathrm{W}=$ warfarin; Dil $=$ diltiazem. 


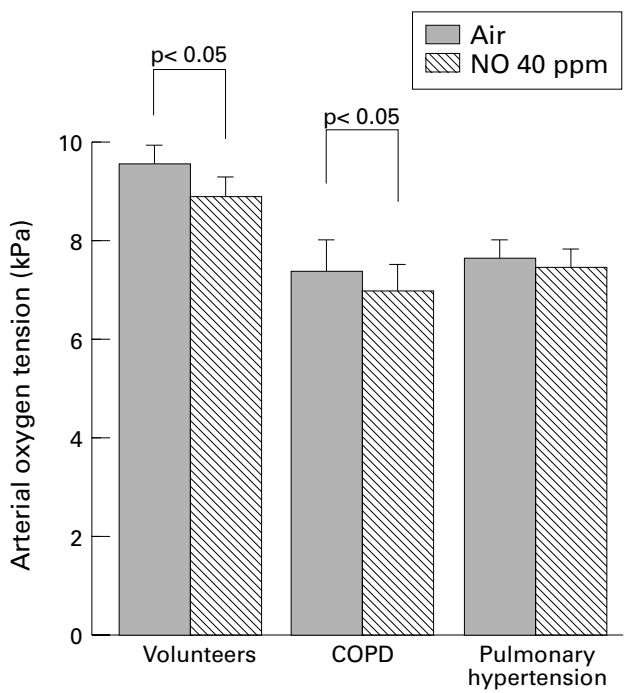

Figure 2 Transcutaneous arterial oxygen tension during 20 minutes breathing 40 ppm nitric oxide (NO) and a similar period of breathing air in patients with chronic obstructive pulmonary disease (COPD), severe pulmonary hypertension, and in volunteers. No change was observed in the arterial oxygen tension in patients with severe pulmonary hypertension, but it was reduced in the normal subjects and the patients with COPD (both $p<0.05$ ) following inhalation of NO.

$<0.05)$ in patients with COPD. In patients with severe pulmonary hypertension $\mathrm{TcPO}_{2}$ was $7.6(0.4) \mathrm{kPa}$ with air and $7.4(0.4) \mathrm{kPa}$ with inhaled NO ( $\mathrm{p}=0.68$; fig 2$)$. No changes occurred in the $\mathrm{TcPCO}_{2}, \mathrm{SaO}_{2}$, or cardiac output in patients or volunteers with inhaled NO (table 3). No significant changes in venous $\mathrm{MetHb} \%$ level were observed during inhaled NO (table 3).

\section{Discussion}

In patients with COPD and in normal subjects the $\mathrm{TcPO}_{2}$ fell during the 20 minute period of breathing $40 \mathrm{ppm}$ of $\mathrm{NO}$ in air; no change in $\mathrm{TcPO}_{2}$ occurred in patients with severe pulmonary hypertension. These observations support the idea that inhaled NO appears to worsen gas exchange in those patients where the change in pulmonary haemodynamics is small. ${ }^{489}$

A concentration of $40 \mathrm{ppm}$ inhaled NO was chosen on the basis of an isolated lung experiment in which pretreatment with the NO synthase inhibitor $\mathrm{N}^{\mathrm{G}}$-nitro-L-arginine caused a fall in PVR which was normalised by $40 \mathrm{ppm}$ and $80 \mathrm{ppm}$ inhaled NO but not by $10 \mathrm{ppm}^{12}$ To ensure that the correct concentration of $\mathrm{NO}$ was administered a nasal CPAP mask was used which is more airtight than a face mask. More- over, the use of two one-way valves ensured that patients were unable to re-breathe expired air. The $\mathrm{SaO}_{2}$ and $\mathrm{NO}$ and $\mathrm{NO}_{2}$ concentrations were monitored to avoid the development of hypoxia and $\mathrm{NO}$ and $\mathrm{NO}_{2}$ toxicity. $\mathrm{NO}$ reacts with oxygen and forms $\mathrm{NO}_{2}$ which can cause airway injury so NO was first mixed with nitrogen and then oxygen (fig 1).

The study was dependent on the accuracy of the non-invasive measurements which were chosen to involve minimal disturbance to the haemodynamics of the study participants. The measurement of $\mathrm{TcPo}_{2}$ was first reported in 1969 by Huch et al. ${ }^{13}$ The sensor allows measurement of $\mathrm{TcPO}_{2}$ which reflects the arterial oxygen pressure $\left(\mathrm{PaO}_{2}\right)^{14}$ in many clinical conditions. We allowed 20 minutes exposure to each gas mixture which is sufficient for the fall in $\mathrm{PaO}_{2}$ to be detected by the $\mathrm{TcPO}_{2} \cdot{ }^{13}$ The low cardiac output and poor tissue perfusion in the patients with severe pulmonary hypertension could have decreased the accuracy of the $\mathrm{TcPO}_{2}$ measurement. However, inhaled NO does not necessarily increase the $\mathrm{PaO}_{2}$ in patients with severe pulmonary hypertension. This is partly explained by the fact that, although the pulmonary artery pressure falls, cardiac output does not increase with inhaled NO. ${ }^{467}$ As previously reported, cardiac output did not change in any of our patient groups (table 3). The transthoracic impedance method of measuring cardiac output is valid in many patient groups ${ }^{11}$ and in normal subjects ${ }^{1516}$ and reliably follows the changes in cardiac output seen with exercise. ${ }^{11}$ An additional explanation for the failure to improve $\mathrm{TcPo}_{2}$ in patients with severe pulmonary hypertension could be the existing vasodilator treatment which will lessen the vasodilator effects of inhaled NO.

Inhaled NO is a selective pulmonary vasodilator, ${ }^{4-7}$ causing relaxation of smooth muscle cells of the pulmonary precapillary resistance arteries. ${ }^{17}$ These vessels are found within the pulmonary acini and the distance of diffusion of inhaled NO into the smooth muscle of these vessels is no greater than into the alveolar capillaries. Most of the inhaled NO is taken up in alveolar capillaries where it combines rapidly with oxyhaemoglobin within red blood cells to form methaemoglobin and nitrate. ${ }^{1819}$ The formation of methaemoglobin effectively inactivates NO which has no subsequent action on the systemic circulation. Our failure to demonstrate a change in venous $\mathrm{MetHb} \%$ agrees with earlier work on short term exposure to $\mathrm{NO}^{5-7}$ and reflects the efficiency of the red blood cell methaemoglobin reductase in restoring iron II haemoglobin. ${ }^{19}$

Table 3 Mean (SE) haemodynamic and gas exchange data on air and after 20 minutes of 40 ppm nitric oxide (NO) inhalation

\begin{tabular}{|c|c|c|c|c|c|c|}
\hline & \multicolumn{2}{|l|}{ Volunteers } & \multicolumn{2}{|l|}{$C O P D$} & \multicolumn{2}{|c|}{ Pulmonary hypertension } \\
\hline & Air & NO & Air & NO & Air & NO \\
\hline Cardiac output (1/min) & $5.2(0.4)$ & $5.1(0.4)$ & $4.3(0.6)$ & $4.4(0.6)$ & $3.3(0.4)$ & $3.4(0.3)$ \\
\hline $\mathrm{TcPCO}_{2}(\mathrm{kPa})$ & $6.6(0.3)$ & $6.5(0.4)$ & $8.1(0.4)$ & $8.0(0.5)$ & $6.3(0.4)$ & $6.3(0.4)$ \\
\hline $\mathrm{TcPO}_{2}(\mathrm{kPa})$ & $9.6(0.3)$ & $8.9(0.4)^{*}$ & $7.4(0.6)$ & $7.0(0.5)^{*}$ & $7.6(0.4)$ & $7.4(0.4)$ \\
\hline $\mathrm{SaO}_{2}(\%)$ & $97.6(0.2)$ & $97.4(0.3)$ & $87.2(2.1)$ & $87.6(1.7)$ & $93.2(0.9)$ & $92.5(1.0)$ \\
\hline Methaemoglobin $(\mathrm{mg} / \mathrm{dl})$ & $0.8(0.1)$ & $0.8(0.1)$ & $1.0(0.2)$ & $0.8(0.1)$ & $0.4(0.1)$ & $0.7(0.1)$ \\
\hline
\end{tabular}

* $\mathrm{p}<0.05$ versus air inhalation. 
Inhaled $\mathrm{NO}$ improves $\mathrm{PaO}_{2}$ in certain lung diseases. In ARDS inhaled NO is distributed to ventilated regions of the lung where it increases perfusion. Probably by a "steal" phenomenon, the inhaled NO lessens blood flow in regions of intrapulmonary shunt by diverting it from the unventilated regions ${ }^{6}$ to ventilated regions. On the other hand, the effect of aerosolised prostacyclin in ARDS has been reported to be the same as inhaled NO. ${ }^{20}$ However, there was still a larger decrease in systemic vascular resistance during aerosolised prostacyclin than during inhaled NO. In persistent pulmonary hypertension of the newborn the $\mathrm{PaO}_{2}$ is also increased by inhaled NO. This is simply by reducing the pulmonary artery pressure which reverses the amount of right to left shunt through the patient's ductus arteriosus. ${ }^{5}$

Patients with COPD do not have high values of pulmonary vascular resistance ${ }^{89}$ and have normal or even raised cardiac output. ${ }^{21}$ Inhaled NO will be expected to have only a minimal haemodynamic effect in these patients. One of the major abnormalities in patients with COPD is the disturbance of the distribution of ventilation. The homogeneity of the distribution of ventilation is reflected by the wide range of time constants. ${ }^{22}$ Conventional NO inhaled at a fixed concentration can be expected to reach regions with both slow and fast ventilation. Furthermore, in diseases such as emphysema collateral ventilation occurs. ${ }^{23}$ We do not know the minimum alveolar concentration of inhaled NO needed to cause pulmonary vasodilation in humans, although concentrations as low as $1 \mathrm{ppm}$ in the inhaled gas mixture can cause vasodilatation. ${ }^{24}$ Alveolar concentrations are likely to be well below this level and yet are effective, so even slow ventilated regions of the lungs in patients with COPD are likely to receive sufficient $\mathrm{NO}$ to overcome hypoxic vasoconstriction. ${ }^{6}$ This, in turn, will lead to poorer matching of $\mathrm{VA} / \mathrm{Q}$ and worsening gas exchange. The pulmonary endothelial production of NO is dependent on alveolar partial pressure of oxygen. ${ }^{25}$ Hypoxia inhibits endothelial NO production ${ }^{26}$ which suggests that it might play a parallel role to the direct action of hypoxia on pulmonary artery tone ${ }^{27}$ in regulating pulmonary blood flow. In diseases such as COPD alveolar hypoxia enhances the matching between the distribution of ventilation and perfusion by reducing perfusion of unventilated regions. Overriding of this effect by inhaled $\mathrm{NO}$ may account for the fall in $\mathrm{TcPO}_{2}$ seen in the patients with COPD and is supported by the observed widening of the distribution of the $\mathrm{VA} / \mathrm{Q}$ in these patients when NO is inhaled. ${ }^{28}$

It is interesting that a similar fall in $\mathrm{TcPO}_{2}$ with inhaled NO was also seen in normal volunteers. As the cardiac output was unchanged it can be concluded that, under resting conditions, matching of ventilation and perfusion is an active process even in healthy subjects. It is possible that pulmonary artery vasoconstriction occurs even in normal subjects and that this is a cause of close matching of $\mathrm{VA} / \mathrm{Q}$. This idea is supported by the fact that, in normal volunteers, inhalation of hyperoxic gas mixtures can cause an increased inequality in $\mathrm{VA} / \mathrm{Q} \cdot{ }^{29} \mathrm{In}$ other words, there is evidence that hypoxic vasoconstriction contributes to the matching of $\mathrm{VA} / \mathrm{Q}$ even in normal subjects.

It can be questioned whether pulmonary endothelial NO subserves a similar function. Whilst inhaled NO does not necessarily improve $\mathrm{PaO}_{2}$ in patients with COPD, it is still effective in other chronic lung diseases. In patients with pulmonary fibrosis ${ }^{30}$ inhaled NO improves arterial oxygenation. These patients, however, behaved like the patients with severe pulmonary hypertension, with marked improvement of pulmonary haemodynamics as well as a rise in $\mathrm{PaO}_{2}$. This serves to emphasise the fact that important differences in the response of patients to inhaled NO depend upon the underlying pathophysiology of the lung disease.

In conclusion, inhaled $\mathrm{NO}$ is a selective pulmonary vasodilator with considerable therapeutic potential. In many diseases it can also improve gas exchange, lessening hypoxaemia. In patients with COPD the gas exchange is not necessarily improved. Existing delivery systems for inhaled NO do not selectively distribute NO to fast ventilated regions alone and so the benefits of hypoxic vasoconstriction are overridden. The same effect of inhaled NO in our volunteers suggests that an element of mismatching between $\mathrm{VA} / \mathrm{Q}$ driven by hypoxic vasoconstriction occurs even in the normal lung.

This work was supported by the H C Roscoe Award of the BMA.

1 Ignarro LJ, Buga GM, Wood KS, Byrns RE, Chaudhuri G. Endothelium-derived relaxing factor produced and
released from artery and vein is nitric oxide. Proc Natl released from artery and vein is
Acad Sci USA 1987;84:9265-9.

2 Palmer RM, Ferrige AG, Moncada S. Nitric oxide release accounts for the biological activity of endothelium-derived relaxing factor. Nature 1987;327:524-6.

3 Ignarro LJ. Biological actions and properties of endothelium derived nitric oxide formed and released from artery and vein. Circ Res 1989;65:1-21.

4 Pepke-Zaba J, Higenbottam TW, Dinh-Xuan AT, Stone D, Wallwork J. Inhaled nitric oxide as a cause of selective pulmonary vasodilatation in pulmonary hypertension. Lancet 1991;338:1173-4.

5 Kinsella JP, Neish SR, Shaffer E, Abman SH. Low-dose inhalation nitric oxide in persistent pulmonary hypertension of the newborn. Lancet 1992;340:819-20.

6 Rossaint R, Falke KJ, Lopez F, Slama K, Pison U, Zapol WM. Inhaled nitric oxide for the adult respiratory distress syndrome. N Engl f Med 1993;328:399-405.

7 Frostell C, Fratacci MD, Wain JC, Jones R, Zapol WM. Inhaled nitric oxide. A selective pulmonary vasodilator Inhaled nitric oxide. A selective pulmonary vasodilator reversing hypoxic puld
1991;83:2038-47.

8 Adnot S, Kouyoumdjian C, Defouilloy C, Andrivet P, Sediame S, Herigault $\mathrm{R}$, et al. Hemodynamic and gas exchange responses to infusion of acetylcholine and inhalation of nitric oxide in patients with chronic obstructive lung disease and pulmonary hypertension. $A m$ Rev Respir Dis 1993;148:310-6.

9 Moinard J, Manier C, Pillet O, Castaing Y. Effect of inhaled nitric oxide on hemodynamics and $\mathrm{Va} / \mathrm{Q}$ inequalities in patients with chronic obstructive pulmonary disease. $A m$ $\mathcal{F}$ Respir Crit Care Med 1994;149:1482-7.

10 Ahluwalia JS, Kelsall AW, Raine J, Rennie JM, Mahmood $\mathrm{M}$, Oduro AL, et al. Safety of inhaled nitric oxide in premature neonates [letter]. Acta Paediatr 1994;83:347-8.

11 Pepke-Zaba J, Higenbottam TW, Dinh Xuan AT, Scott JP, English TAH, Wallwork J. Validation of impedance cardiography measurements of cardiac output during limited exercise in heart transplant recipients. Transplant Int 1990;3:108-12.

12 Cremona GI. Nitric oxide and pulmonary vascular resistance in health and disease. $\mathrm{PhD}$ thesis. Cambridge: Cambridge University, 1994: 1-227.

13 Huch A, Huch R, Lubbers DW. Quantitative polarographic measurement of the oxygen pressure on the scalp of the newborn. [German]. Archiv Gynakol 1969;207:443-51.

14 Fenner A, Muller R, Busse HG, Junge M, Wolfsdorf J Transcutaneous determination of arterial oxygen tension. Pediatrics 1975;23:64-6. 
15 Sramek BB. Noninvasive technique for measurement of cardiac output by means of electrical impedance. In: Proceedings of the fifth international conference on electrical bioimpedance, Tokyo. 1981: 39-42.

16 Sramek BB, Rose DM, Miyamoto A. Stroke volume equation with a linear base impedance model and its accuracy, as compared to the thermodilution and magnetic flowmeter techniques in humans and animal. In: Proceedings of the sixth international conference on electrical bioimpedance, Zadar. 1983: 38-41.

17 Cremona G, Takao M, Bower EA, Hall LW, Higenbottam T. The effects of hypoxia, inhaled nitric oxide and endothelial nitric oxide on total and segmental vascular resistance of isolated pig lungs. F Appl Physiol 1996 (in press).

18 Yoshida K, Kasama K, Kitabatake M, Okuda M. Metabolic fate of nitric oxide. Int Arch Occup Environ Health 1980; 48:71-7.

19 Wennmalm A, Benthin G, Petersson A-S. Dependence of the metabolism of nitric oxide (NO) in healthy human whole blood on the oxygenation of its red cell haemoglobin. Br f Pharmacol 1992;106:507-8.

20 Walmrath D, Schneider T, Pilch J, Grimminger F, Seeger W. Aerosolised prostacyclin in adult respiratory distress syndrome. Lancet 1993;342: 961-2.

21 Lockhart A, Trareva M, Schrijen F, Sadoul P. Etude des hemodynamiques des decompensations respiratoires aigues des bronchopneumopathies chroniques. [French]. Bull Physio-Pathol Respir 1967;3:645-67.

22 Agusti AGN, Barbera JA. Contribution of multiple inert gas elimination technique to pulmonary medicine. 2: Chronic pulmonary diseases:chronic obstructive pulmonary disease and idiopathic pulmonary fibrosis. Thorax 1994;49:92432.

23 Morrell NW, Wignall BK, Biggs T, Seed A. Collateral ventilation and gas exchange in emphysema. Am $\mathcal{F}$ Respir Crit Care Med 1994;150:635-41.

24 Puybasset L, Rouby JJ, Mourgeon E, Stewart TE, Cluze $\mathrm{P}, \mathrm{Belin} \mathrm{MF}$, et al. Inhaled nitric oxide in acute respiratory failure: dose-response curves. Intensive Care Med 1994;20. 319-27.

G, Katayama Y, Bower EA, Butt AY, Higenbottam T. Basal and stimulated release of nitric oxide (NO) in isolated human lungs with severe pulmonary hypertension (SPH). Am 7 Respir Crit Care Med 1995; 151: A626.

26 Warren JB, Maltby NH, MacCormack D, Barnes PJ. Pulmonary endothelium-derived relaxing factor is impaired in hypoxia. Clin Sci 1989;77:671-6.

27 Cremona G, Wood AM, Hall LW, Bower EA, Higenbottam TW. Effects of inhibitors of nitric oxide release and action on vascular tone in isolated lungs of pig, sheep, dog and man. F Physiol Lond 1994;481.1:185-95.

28 Wagner PD, Laravuso RB, Uhl RR, West JB. Continuous distribution of ventilation-perfusion ratios in normal subjects breathing air and 100 percent $\mathrm{O}_{2}$ f Clin Invest 1974 54:54-68.

29 Barbera JA, Roger N, Roca J, Rovira I, Higenbottam TW, Rodriguez-Roisin R. Worsening of gas exchange with nitric oxide inhalation in chronic obstructive pulmonary disease. Am $\mathcal{F}$ Respir Crit Care Med 1995;151:A726.

30 Channick RN, Hoch RC, Newhart JW, Johnson FW, Smith $\mathrm{CM}$. Improvement in pulmonary hypertension and hypoxemia during nitric oxide inhalation in patients with endstage pulmonary fibrosis. Am $\mathcal{F}$ Respir Crit Care Med 1994. 149:811-4. 